\title{
ANALISIS PEMBIAYAAN MUSYARAKAH TERHADAP PROFITABILITAS (ROA) BANK UMUM SYARIAH
}

\author{
Alimatul Farida \\ farida@yudharta.ac.id \\ Universitas Yudharta Pasuruan
}

\begin{abstract}
This study aims to determine the effect of musyarakah financing on the profitability of sharia commercial banks in Indonesia using the Return on Assets (ROA) ratio. The research methodology used is descriptive qualitative research. By analyzing the data, it tends to study literature. The results showed that the musharaka financing had a significant negative effect on the profitability (ROA) of Islamic banks.
\end{abstract}

Keywords: Musharaka, Financing, Profitability, ROA

\begin{abstract}
Abstrak: Penelitian ini bertujuan untuk mengethaui pengaruh pembiayaan musyarakah terhadap Profitabilitas Bank Umum syariah di Indonesia dengan menggunakan rasio Return on Assets (ROA). Metodologi penelitian yang digunakan adalah penelitian deskriptif kualitatif. Dengan menganalisis data cenderung Studi Pustaka. Hasil penelitian menunjukkan bahwa pembiayaan musyarakah berpengaruh negative signifikan terhadap Profitabilitas (ROA) Bank Umum syariah.
\end{abstract}

Kata Kunci: Musyarakah, Pembiayaan, Profitabilitas, ROA

\section{PENDAHULUAN}

Lembaga keuangan Islam saat ini bukan merupakan hal yang asing lagi di dunia, baik Negara Islam maupun Negara non-Islam. Di Indonesia, lembaga keuangan Islam saat ini mengalami perkembangan yang cukup pesat. Hal ini ditandai dengan semakin banyaknya lembaga-lembaga keuangan Islam yang berdiri di Indonesia dibandingkan dengan beberapa tahun yang lalu. Terbukti sejak tahun 1991 sampai dengan 2016, telah banyak berdiri berbagai lembaga keuangan Islam salah satunya Bank Muamalat Indonesia yang merupakan Bank Islam pertama di Indonesia. Sampai saat ini berbagai bank Islam telah muncul di Indonesia. Selain itu juga telah muncul lembaga keuangan Islam lainnya seperti Asuransi Islam, Pengadaian Islam, dan lembaga keuangan mikro Islam. Lembaga keuangan 
mikro Islam juga mengalami perkembangan yang sangat berarti. Lembaga keuangan mikro Islam mempunyai peran sebagai wadah penyaluran maupun permodalan dana bagi masyarakat kalangan menengah kebawah sehingga mampu menjadi salah satu unsur dalam perkembangan perekonomian di Indonesia ${ }^{1}$.

Perkembangan perekonomian mempunyai kaitan erat dengan dunia keuangan dan lembaga keuangan. Lembaga keuangan di Indonesia salah satunya sampai dengan sekarang ini yang dapat dijadikan sebagai salah satu alternative untuk mendukung pertumbuhan perekonomian di Indonesia adalah Lembaga Keuangan Syariah. Diantaranya ada perbankan islam atau perbankan syariah.

Perbankan islam atau selanjutnya disebut dengan bank syariah adalah bank yang beroperasi dengan tidak mengandalkan pada bunga. Bank islam atau bisa dengan bank tanpa bunga adalah lembaga keuangan/perbankan yang operasional dan produknya dikembangkan berlandaskan pada al-Qur'an dan Hadits Nabi Saw. Atau dengan kata lain bank islam adalah lembaga keuangan yang usaha pokoknya memberikan pembiayaan dan jasa jasa lainnya dalam lalu lintas pembayaran serta peredaran uang yang pengoperasiannya disesuaikan prinsip syariah islam ${ }^{2}$.

Perbankkan syariah sebagai bentuk implementasi konsep ekonomi syariah mempunyai spirit keberpihakan kepada sector riil terutama usaha menengah ke bawah ${ }^{3}$. Perbankan syariah yang tidak mengenal bunga, namun menawarkan kontrak kerjasama yang saling menguntungkan antara pihak bank syariah (pemilik modal) dengan nasabah (pengelola usaha) dalam kontrak hubungan investasi antara bank syariah dan nasabahnya disebut dengan istilah pembiayaan. Pembiayaan adalah pendanaan yang diberikan oleh satu pihak kepada pihak lain untuk mendukung investasi yang telah direncanakan, baik yang dilakukan sendiri maupun oleh lembaga.

Berdasarkan publikasi statistika perbankan syariah yang dilakukan oleh Otoritas Jasa Keuangan (OJK) menunjukkan bahwa akad yang paling berkembang pesat dan mengalami peningkatan setiap tahunnya dalam

\footnotetext{
1 Ernanda Kusuma Dewi dan Ayu Lestari, Peran Pembiayaan Mudharabah Dalam Pengembangan Kinerja Usaha Mikro Pada BMT (Baitul Maal Wat Tamwil), Jurnal Law and Justice, Vol. 2, No. 2, Oktober 2017, h. 113 - 114.

${ }^{2}$ Muhammad. Manajemen Dana Bank Syariah. Jakarta: Raja Grafindo Persada. 2017, h. 2

${ }^{3}$ Hamdan. Pengaruh Pembiayaan Mudharabah dan Musyarakah terhadap NPF pada Bank Umum syariah. Artikel Ilmiah. Surabaya. 2013.
} 
pembiayaan di bank syariah adalah akad mudharabah, musyarakah dan murabahah $^{4}$. Hal ini menunjukkan bahwa minat masyarakat terhadap pembiayaan cukup besar. Setiap produk yang dikeluar oleh bank mempunyai tujuan untuk mendapatkan keuntungan atau laba bagi pihak bank. Rasio profitabilitas merupakan rasio yang menggambarkan laba yang dihasilkan perusahaan $^{5}$.

Musyarakah adalah akad kerjasama antara dua belah pihak atau lebih untuk usaha tertentu, dimana masing masing pihak memberikan kontribusi dana dengan ketentuan bahwa keuntungan dibagi berdasarkan kesepakatan sedangkan kerugian berdasarkan porsi kontribusi berdasarkan kas maupun asset non kas yang diperkenankan oleh syariah ${ }^{6}$. Ascarya dalam bukunya yang berjudul akad dan produk bank syariah mengatakan musyarakah merupakan akad bagi hasil ketika dua atau lebih pengusaha pemilik dana/modal bekerja sama sebagai mitra usaha membiayai investasi usaha baru atau yang sudah berjalan ${ }^{7}$.

Penelitian ini bertujuan untuk mengetahui bahwa pembiayaan musyarakah memberikan pengaruh positif terhadap peningkatan profitabilitas (ROA), yang sejalan dengan penelitian Felani $\mathrm{dkk}^{8}$.

\section{KAJIAN TEORI}

\section{Pengertian Pembiayaan}

Dalam UU No. 10 tahun 1998 tentang Perbankan dijelaskan bahwa pembiayaan adalah penyediaan uang atau tagihan yang dapat dipersamakan dengan itu, berdasarkan persetujuan atau kesempatan antara lembaga keuangan dengan pihak lain yang mewajibkan pihak yang dibiayai untuk mengembalikan uang atau tagihan tersebut setelah jangka waktu dengan imbalan atau bagi hasil ${ }^{9}$. Sedangkan menurut Muhammad

\footnotetext{
${ }^{4}$ Anisa Dwi F., Rimi Gusliana M., Pengaruh Pembiayaan Mudharabah, Musyarakah, dan Murabahah terhadap ROA melalui NPF sebagai Variabel Intervening. Jurnal Akuntansi dan Manajemen. 16 (7). 2017, h. 2.

${ }^{5}$ Hery, Analisis Kinerja Manajemen: The Best Financial Analisis Menilai Kinerja Manajemen Berdasarkan Rasio Keuangan (Jakarta: Raja Grafindo Persada, 2015), h. 143

${ }^{6}$ Wiroso. Akuntansi Perbankan Syariah dalam Praktek Di Indonesia. Risalah PErbankan Syariah. Jagakarsa. 2014.h. 7-6

${ }^{7}$ Ascarya. Bank dan Produk Bank Syariah. Jakarta: Rajawali Pers. 2012, h.51.

8 Felani, H. Setiawiani, I.G. Pengaruh Pendapatan Mudharabah, Musyarakah dan Murabahah Terhadap Profitabilitas Bank Umum Syariah Periode 2013-2015. Seminar Nasional dan The $4^{\text {th }}$ Call For Syariah Paper. 2017, h. 15.

${ }^{9}$ Undang-undang Republik Indonesia Nomor 10 tahun 1998 tentang Pembiayaan
} 
pembiayaan atau financing adalah pendanaan yang diberikan oleh suatu pihak kepada pihak lain untuk mendukung investasi yang telah direncanakan, baik dilakukan sendiri maupun lembaga ${ }^{10}$.

Berdasarkan persetujuan atau kesepakatan antara bank syariah dan atau LKS dan pihak lain yang mewajibkan pihak yang dibiayai atau diberi fasilitas dana mengembalikan dana tersebut setelah jangka waktu tertentu dengan imbalan ujrah, bagi hasil atau tanpa imbalan ${ }^{11}$.

Berdasarkan pengertian diatas, dapat disimpulkan bahwa pembiayaan adalah penyediaan uang atau tagihan atau pemberian fasilitas penyediaan dana untuk berbagai macam transaksi seperti transaksi bagi hasil, sewa-menyewa, jual beli, pinjam-meminjam yang didasarkan pada kesepakatan antar beberapa pihak pihak/kesepakatan antara bank dengan pihak lain yang mewajibkan pihak yang dibiayai untuk mengembalikan uang atau tagihan tersebut setelah jangka waktu tertentu dengan imbalan atau bagi hasil.

\section{Dasar Hukum Pembiayaan}

a. Dalam Surat An - Nisa Ayat 29 berbunyi :

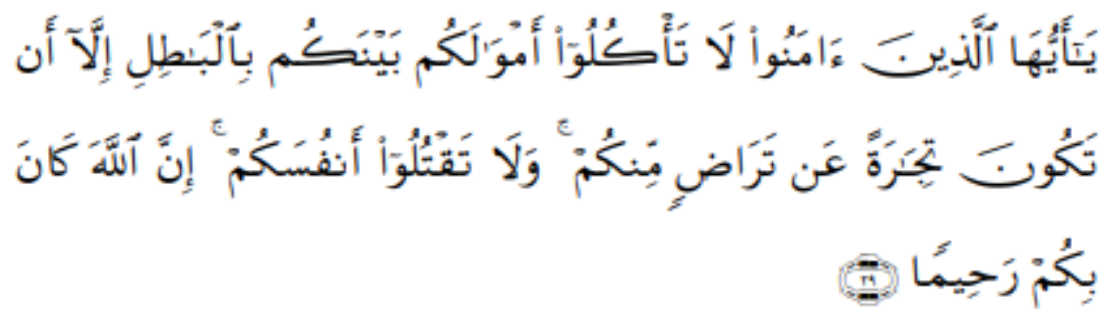

Artinya: Hai orang-orang yang beriman, janganlah kamu saling memakan harta sesamamu dengan jalan batil, kecuali dengan jalan perniagaan yang berlaku dengan suka sama suka diantara kamu. Dan janganlah kamu membunuh dirimu, sesungguhnya Allah adalah Maha penyayang kepadamu.(Q.S An-nisaa':29) ${ }^{12}$

b. Firman Allah dalam pembiayaan atau hutang dalam surat $\mathrm{Al}$ - Baqarah ayat $280:{ }^{13}$

${ }^{10}$ Muhammad, Manajemen Pembiayaan Bank Syariah, (Yogyakarta: UUP AMP YKPN, 2005), h. 17.

${ }^{11}$ Usanti, Trisadini P. dan Abd. Somad, Transaksi Bank Syariah, (Jakarta: Bumi Aksara, 2013), h. 9.

12 Departemen Agama, Mushaf Al Quran dan terjemah (Bogor:NUR no P.VI/1/TL.02.1/410/2009) h.83.

${ }^{13}$ Ibid, h. 47 


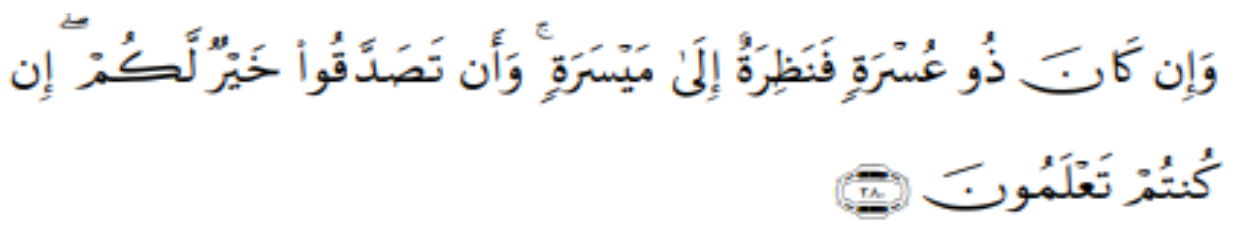

Artinya: Dan jika (orang yang berhutang itu) dalam kesulitan, Maka berilah tenggang waktu sampai Dia memperoleh kelapangan. Danjika kamu menyedekahkan (sebagian atau semua utang) itu, lebih baik bagimu, jika kamu mengetahui. (QS. Al Baqarah: 280)

c. Dalam kaidah Fikih di sebutkan bahwa :

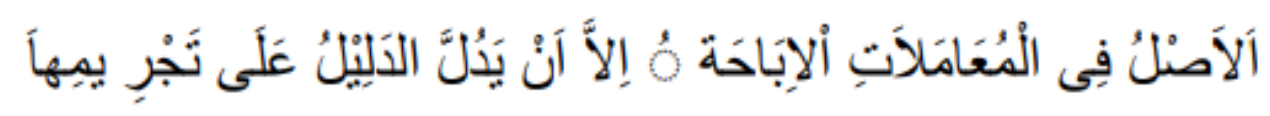

Artinya: Pada dasarnya, semua bentuk muamalah boleh dilakukan kecuali ada dalil yang mengharamkannya.

\section{Akad Musyarakah}

a. Pengertian Musyarakah

Dilarangnya praktik riba dalam bidang muamalat perbankan Islam oleh ketentuan Al-Qur'an dan As-Sunnah maka dalam ajaran Islam diberikan metode lain salah satunya yaitu musyarakah. Kata musyarakah bersumber dari akar kata $s y-r$-k, yang dalam Al-Qur'an disebutkan sebanyak lebih kurang 170 kali walau tak satu pun dari ayat ini yang menggunakan istilah musyarakah persis dengan arti kemitraan dalam suatu kongsi bisnis. Istilah lain yang digunakan untuk musyarakah adalah syarikah atau syirkah. Dalam bahasa inggris, musyarakah diterjemahkan dengan istilah partnership, sedangkan oleh lembaga-lembaga keuangan Islam menerjemahkannya dengan istilah participation financing. Dalam bahasa Indonesia dapat diterjemahkan dengan kemitraan, persekutuan atau perkongsian. $^{14}$

Secara bahasa Musyarakah berasal dari kata al-syirkah yang berarti al-ikhtilath (percampuran) atau persekutuan dua hal atau lebih, sehingga antara masing-masing sulit dibedakan. Seperti persekutuan hak milik atau perserikatan usaha. ${ }^{15}$ Secara etimologis, musyarakah adalah

\footnotetext{
${ }^{14}$ Osmad Muthaher, Akuntansi Perbankan Syariah, (Yogyakarta: Graha Ilmu, 2012), 163164

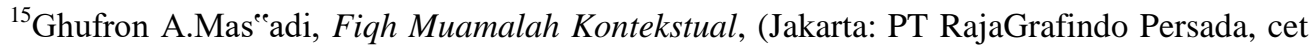
ke-1, 2002), 191
} 
penggabungan, percampuran atau serikat. ${ }^{16}$ Secara fiqih, dalam kitabnya, as-Sailul Jarrar III: 246 dan 248, Imam Asy-Syaukani menulis sebagai berikut, (Syirkah syar'iyah) terwujud (terealisasi) atas dasar sama-sama ridha di antara dua orang atau lebih, yang masing-masing dari mereka mengeluarkan modal dalam ukuran yang tertentu. Kemudian modal bersama itu dikelola untuk mendapatkan keuntungan, dengan syarat masing-masing di antara mereka mendapat keuntungan sesuai dengan besarnya saham yang diserahkan kepada syirkah tersebut. Namun manakala mereka semua sepakat dan ridha, keuntungannya dibagi rata antara mereka, meskipun besarnya modal tidak sama, maka hal itu boleh dan sah, walaupun saham sebagian mereka lebih sedikit sedang yang lain lebih besar jumlahnya. Dalam kacamata syariat, hal seperti ini tidak mengapa, karena usaha bisnis itu yang terpenting didasarkan atas ridha sama ridha, toleransi dan lapang dada. ${ }^{17}$

Musyarakah adalah akad kerjasama yang terjadi di antara para pemilik modal (mitra musyarakah) untuk menggabungkan modal dan melakukan usaha secara bersama dalam suatu kemitraan, dengan nisbah pembagian hasil sesuai dengan kesepakatan, sedangkan kerugian ditanggung secara proporsional sesuai dengan kontribusi modal. ${ }^{18}$

\section{b. Dasar Hukum Musyarakah}

Musyarakah merupakan akad yang diperbolehkan berdasarkan Alqur'an, sunnah, dan ijma'.

1) Al Qur'an

a) "Tetapi jika saudara-saudara seibu itu lebih dari seorang, maka mereka bersekutu dalam yang sepertiga itu”. (Q.S An Nisa : 12)

b) "Dari sesungguhnya kebanyakan dari orang-orang yang berserikat itu sebagian mereka berbuat zalim kepada sebagian yang lain, kecuali orang-orang yang beriman dan mengerjakan amal yang shaleh; dan amat sedikitlah mereka ini". (Q.S Shaad : 24)

2) Hadist

a) Hadist riwayat Abu Daud dari Abu Hurairah, Rasulullah SAW bersabda: "Allah SWT berfirman: „Aku adalah pihak ketiga dari dua orang yang bersyarikat selama salah satu pihak tidak

\footnotetext{
${ }^{16}$ Mardani, Hukum Bisnis Syariah, (Jakarta: Prenadamedia Group, cet ke-1, 2014), 142

${ }^{17} \mathrm{Naf}^{\mathrm{e}}$ an, Pembiayaan Musyarakah dan Mudharabah, (Yogyakarta: Graha Ilmu, cet ke-1, 2014), 96

${ }^{18}$ Naf'an, Pembiayaan Musyarakah dan...., h.95
} 
mengkhianati pihak yang lain. Jika salah satu pihak telah berkhianat, Aku keluar dari mereka." (HR. Abu Daud, yang dishahihkan oleh al-Hakim, dri Abu Hurairah).

b) Hadis Nabi riwayat Tirmidzi dari Amr bin Auf: "Perdamaian dapat dilakukan di antara kaum muslimin kecuali perdamaian yang mengharamkan yang halal atau menghalalkan yang haram; dan kaum muslimin terikat dengan syarat-syarat mereka kecuali syarat yang mengharamkan yang halal atau menghalalkan yang haram."

3) Ijma

Ibnu Qudamah dalam kitabnya, al Mughni, telah berkata: "Kaum muslimin telah berkonsensus terhadap legitimasi masyarakat secara global walaupun terdapat perbedaan pendapat dalam beberapa elemen darinya". ${ }^{19}$

\section{c. Manfaat Musyarakah}

Terdapat banyak manfaat dari pembiayaan musyarakah ini, di antaranya sebagai berikut:

1) Bank akan menikmati peningkatan dalam jumlah tertentu pada saat keuntungan usaha nasabah meningkat.

2) Bank tidak berkewajiban membayar dalam jumlah tertentu kepada nasabah pendanaan secara tetap, tetapi disesuaikan dengan pendapatan/hasil usaha bank, sehingga bank tidak akan pernah mengalami negative spread.

3) Pengembalian pokok pembiayaan disesuaikan dengan cash flow/arus kas usaha nasabah, sehingga tidak memberatkan nasabah.

4) Bank akan lebih selektif dan hati-hati mencari usaha yang benarbenar halal, aman, dan menguntungkan. Hal ini karena keuntungan yang riil dan benar-benar terjadi itulah yang akan dibagikan.

5) Prinsip bagi hasil dalam musyarakah ini berbeda dengan prinsip bunga tetap di aman bank akan menagih penerima pembiayaan (nasabah) satu jumlah bunga tetap berapapun keuntungan yang dihasilkan nasabah, bahkan sekalipun merugi dan terjadi krisis ekonomi. $^{20}$

\footnotetext{
${ }^{19}$ Muhammad Syafie ${ }^{\text {ei }}$ Antonio, Bank Syariah: Dari Teori..., h.91

${ }^{20}$ Ismail, Perbankan Syariah...., h. 103.
} 


\section{Profitabilitas}

Salah satu hal yang menarik bagi pemilik usaha atau pemegang saham adalah profitabilitas. Profitabilitas pada umumnya merupakan pengukuran mengenai kemampuan bank untuk menghasilkan laba dan asset yang digunakan. Ada beberapa rasio yang paling umum digunakan dalam pengukuran profitabilitas salah satunya adalah ROA (Return On Asset).

Menurut sudana, profitabilitas adalah rasio untuk mengukur kemampuan perusahaan untuk mendapatkan keuntungan dengan memanfaatkan sumber daya yang dimiliki perusahaan ${ }^{21}$. Sedangkan menurut fahmi rasio profitabilitas adalah rasio ini mengukur efektifitas manajemen perusahaan secara keseluruhan yang ditujukan oleh besar kecilnya tingkat keuntungan yang diperoleh dalam hubungannya dengan penjualan dan investasi ${ }^{22}$.

Menurut Kasmir, ROA digunakan untuk menunjukkan kemampuan perusahaan menghasilkan laba dengan menggunakan total asset yang dimiliki. ROA menunjukkan kemampuan perusahaan dalam menghasilkan laba dari kativa yang digunakan ${ }^{23}$. ROA merupakan rasio penting yang digunakan diantara rasio profitabilitas lainnya. ROA diperoleh dengan cara membandingkan laba bersih setelah pajak terhadap total aktiva. Secara matematis ROA dapat dirumuskan sebagai berikut

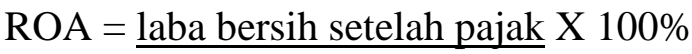

Total aktiva

\section{METODOLOGI}

Dalam penulisan artikel peneliti menggunakan pendekatan deskriptif kualitatif di mana penelitian ini lebih condong kepada studi pustaka. Dan analisis data yang digunakan bertitik tolak dari analisis empiris, yang dalam pendalamannya dilengkapi dengan analisis yuridis. Berdasarkan hasil analisis secara deduktif, yaitu penarikan kesimpulan dari keadaan yang umum atau dengan kata lain dari sejumlah bahasan yang umum maka dilakukan penarikan kesimpulan dengan hal-hal yang lebih khusus ${ }^{24}$.

\footnotetext{
${ }^{21}$ Sudana. Manajemen Keuangan Perusahaan. Jakarta:Erlangga. 2015, h.22

${ }^{22}$ Fahmi, Irham. Analisis Kinerja Keuangan. Bandung:Alfabeta. 2012, h.68.

${ }^{23}$ Kasmir. Analisis Laporan Keuangan. Jakarta: PT. Grafindo Raja Persada. 2016,h.201.

${ }^{24}$ Sugiono. Metode Penelitian Pendidikan. Bandung: Alfabeta, 2015.
} 


\section{PEMBAHASAN}

Secara umum prinsip bagi hasil dalam perbankan syariah dapat dilakukan dalam empat akad utama, yaitu al-musyarakah, al-mudharabah, almuzara'ah dan al-musaqah. Dari keempat prinsip tersebut yang paling umum dan paling banyak diminati masyarakat adalah al-musyarakah dan almudharabah.

Al-musyarakah adalah akad kerjasama antara dua pihak atau lebih untuk suatu usaha tertentu dimana masing masing pihak memberikan kontribusi dana dengan kesepakatan bahwa keuntungan dan resiko akan ditanggung bersama sesuai dengan kesepakatan. Berdasarkan publikasi perbankan syariah yang dilakukan oleh pihak Otoritas Jasa Keuangan, akad mudharabah, musyarakah dan murabahah mengalami kenaikan setiap tahunnya dalam pembiayaan. Berikut data yang menunjukkan perkembangan tsb.

Table 1. Pembiayaan Perbankan Syariah

\begin{tabular}{|c|c|c|c|c|c|c|}
\hline Akad & \multicolumn{1}{|c|}{2013} & 2014 & \multicolumn{1}{c|}{2015} & \multicolumn{1}{c|}{2016} & \multicolumn{1}{c|}{2017} & 2018 \\
\hline Mudharabah & 13.625 & 14.354 & 14.820 & 15.292 & 17.090 & 15.970 \\
\hline Musyarakah & 39.874 & 49.336 & 60.713 & 78.421 & 101.561 & 112.349 \\
\hline Murabahah & 110.565 & 117.371 & 122.111 & 139.536 & 150.276 & 152.022 \\
\hline Total & $\mathbf{1 6 4 . 0 6 4}$ & $\mathbf{1 8 1 . 0 6 1}$ & $\mathbf{1 9 7 . 6 4 4}$ & $\mathbf{2 3 3 . 2 4 9}$ & $\mathbf{2 6 8 . 9 2 7}$ & $\mathbf{2 8 0 . 3 4 1}$ \\
\hline
\end{tabular}

Sumber: Statistik Perbankan Syariah, Otoritas Jasa Keuangan

Namun kenaikan pembiayaan tersebut tidak diikuti dengan meningkatnya tingkat profitabilitas Bank Umum Syariah yang ditunjukkan dari rasio prosentase ROA. Berikut data yang menyajikan ROA.

Table 2. Rasio Return on Asset (ROA)

\begin{tabular}{|l|c|c|c|c|c|c|l|}
\hline Rasio & 2013 & 2014 & 2015 & 2016 & 2017 & 2018 & 2019 \\
\hline ROA & $2.00 \%$ & $1.19 \%$ & $1.15 \%$ & $0,63 \%$ & $0,63 \%$ & $1.28 \%$ & $1.88 \%$ \\
\hline \multicolumn{1}{c|}{ Sumber: Statistik Perbankan Syariah, Otoritas Jasa Keuangan }
\end{tabular}

Dari data rasio ROA diatas menunjukkan bahwa dengan kenaikan pembiayaan musyarakah setiap tahunnya belum tentu di ikuti kenaikan profitabilitas (ROA), terbukti di tahun 2013 rasio ROA sebesar 2.00\%, kemudian di tahun tahun berikutnya terjadi penurunan sampai dengan ditahun 2017 turun menjadi 0,63\%.

Hal ini tidak sejalan dengan ismail ${ }^{25}$ yang menyatakan bahwa pembiayaan berpengaruh pada peningkatan profitabilitas bank. Hal ini dapat

\footnotetext{
${ }^{25}$ Ismail. Perbankan Syariah. Jakarta: Kencana. 2016, h. 87.
} 
tercermin pada perolehan laba. Dengan adanya peningkatan laba usaha bank akan menyebabkan kenaikan profitabilitas bank.

Dalam beberapa penelitian lain yang mengatakan bahwa pembiayaan musyarakah tidak berpengaruh terhadap peningkatan prifitabilitas antara lain;

1) Anita Dwi F dan Rismi Gusliana M. dengan judul "Pengaruh Pembiayaan Mudharabah, Musyarakah Dan Murabahah Terhadap ROA Melalui NPF Sebagai Variable Intervening" menyebutkan bahwa pembiayaan mudharabah, musyarakah dan murabahah berpengaruh negative terhadap $\mathrm{ROA}^{26}$.

2) Laila Rokhmah, dkk dengan judul P"embiayaan Mudharabah Dan Musyarakah Terhadap Profitabilitas Pada Bank Umum Syariah Di Indonesia" menyebutkan bahwa pembiayaan mudharabah berpengaruh signifikan terhadap profitabilitas sedangkan pembiayaan musyarakah tidak berpengaruh signifikan terhadap profitabilitas ${ }^{27}$.

3) Ahmad Nawawi, dkk dengan judul "Pengaruh Pembiayaan Mudharabah dan Musyarakah terhadap Profitabilitas (ROA) pada BPRS HIK Bekasi" menunjukkan bahwa hasil penelitiannya bahwa pembiayaan mudharabah berpengaruh positif tidak signifikan terhadap profitabilitas ROA sedangkan pembiayaan musyarakah berpengaruh negative terhadap profitabilitas $^{28}$.

4) Medina A., Rina M. "Analisis Pengaruh Pembiayaan Musyarakah terhadap PRofitabilitas Bank Syariah di Indonesia", hasil penelitian menunjukkan bahwa pembiayaan musyarakah berpengaruh negative terhadap profitabilitas (ROA) Bank Syariah ${ }^{29}$.

5) Ipat Latipah, "Laba Bank Umum Syariah Ditinjau Dari Pembiayaan Musyarakah, Mudharabah Dan Murabaha" hasil penelitiannya

\footnotetext{
${ }^{26}$ Anisa Dwi F., Rimi Gusliana M., Pengaruh Pembiayaan Mudharabah, Musyarakah, dan Murabahah terhadap ROA melalui NPF sebagai Variabel Intervening. Jurnal Akuntansi dan Manajemen. 16 (7). 2017, h. 2

27 Laila R, Euis Komariah. Pembiayaan Mudharabah dan Musyarakah terhadap Profitabilitas pada Bank Umum Syariah di Indonesia. Jurnal Ilmia MBiA 16 (1). 2017, h. 11-20.

28 Ahmad nawawi, dkk. Pengaruh Pembiayaan Mudharabah dan Musyarakah terhadap Profitabilitas (ROA) pada BPRS HIK Bekasi. Falah Jurnal Ekonomi Syariah 3 (2). 2018, h. 1.

${ }^{29}$ Medina A., Rina M. Analisis Pengaruh Pembiayaan Musyarakah terhadap Profitabilitas Bank Syariah di Indonesia. Jurnal Akuntansi 12 (2). 2017, h. 187.
} 
menunjukkan bahwa pembiayaan musyarakah tidak terdapat pengaruh terhadap laba bersih Bank Umum Syariah ${ }^{30}$

6) Ali Muhammad Abdur Rouf, "Pengaruh Pembiayaan terhadap PRofitabilitas (ROA) Bank Syariah dengan Inflasi sebagai Variabel Moderating" menunjukkan bahwa variable musyarakah berpengaruh negative signifikan terhadap profitabilitas ${ }^{31}$.

7) Nur Anim Jauhariyah, Dwi Hanifatul M. “Analisis Pembiayaan Mudharabah dan Musyarakah terhadap Profitabilitas Bank di PT. BNI Syariah per 2010 - 2018" menunjukkan bahwa pembiayaan musyarakah secara parsial tidak signifikan.

Dari beberapa penelitian yang berdasarkan data data bank Umum syariah yang sudah dilakukan pengujian dan analisis data bahwa rata rata menyebutkan pembiayaan musyarakah berpengaruh negative signifikan terhadap Profitabilitas (ROA). Hal ini menunjukkan bahwa semakin besar pembiayaan musyarakah akan brdampak pada penurunan profitabilitas (ROA). Pengaruh negative tersebut dapat disebabkan oleh resiko dari pembiayaan musyarakah yang cukup besar sehingga berpengaruh pada Profitabilitas (ROA) dengan kata lain bahwa ada factor ketidakpastian dalam bisnis sehingga tidak luput dari resiko. Meskipu pembiayaan musyarakah daari tahun ke tahun (tahun 2009 - 2019) selalu mengalami kenaikan akan tetapi pendaptan yang diperoleh dari penyaluran Pembiayaan musyarakah masih belum mampu mengoptimalkan kemampuan bank syariah dalam menghasilkan laba.

Jadi semakin besar nilai pembiayaan musyarakah yang disalurkan belum tentu profitabilitas (ROA) yang dihasilkan mengalami kenaikan. Karena pembiayaan musyarakah ini bertujuan sebagai pembiayaan bagi hasil yang untuk membiayai suatu investasi.

\section{KESIMPULAN}

Berdasarkan analisis data dan pembahasan, dapat disimpulkan bahwa Pembiayaan Musyarakah berpengaruh negative signifikan terhadap profitabilitas (ROA) Bank Umum syariah. Artinya semakin tinggi penyaluran

\footnotetext{
30 Ipat Latipah. Laba Bank Umum Syariah Ditinjau Dari Pembiayaan Musyarakah, Mudharabah Dan Murabahah. ProdiManajemen Universita Djuanda. Bogor Jawa Barat. 2015 .

${ }^{31}$ Ali Muhammad Abdur Rouf, "Pengaruh Pembiayaan terhadap Profitabilitas (ROA) Bank Syariah dengan Inflasi sebagai Variabel Moderating. Skripsi. 2018.
} 
dana pembiayaan musyarakah belum tentu menaikkan keuntungan bagi bank umum syariah. Karena pengaruh negative ini dapat disebabkan oleh resiko pembiayan musyarakah yang cukup besar dan tujuan pembiayaan musyarkah adalah bagi hasil untuk iinvestasi bukan untuk meningkatkan laba bank umum syariah.

\section{DAFTAR PUSTAKA}

Ahmad nawawi, dkk. (2018) Pengaruh Pembiayaan Mudharabah dan Musyarakah terhadap Profitabilitas (ROA) pada BPRS HIK Bekasi. Falah Jurnal Ekonomi Syariah 3 (2).

Ali Muhammad Abdur Rouf. (2018). Pengaruh Pembiayaan terhadap Profitabilitas (ROA) Bank Syariah dengan Inflasi sebagai Variabel Moderating. Skripsi.

Anisa Dwi F., Rimi Gusliana M., (2017) Pengaruh Pembiayaan Mudharabah, Musyarakah, dan Murabahah terhadap ROA melalui NPF sebagai Variabel Intervening. Jurnal Akuntansi dan Manajemen. 16 (7).

Ascarya. (2012). Bank dan Produk Bank Syariah. Jakarta: Rajawali Pers.

Departemen Agama, Mushaf Al Quran dan terjemah (Bogor:NUR no P.VI/1/TL.02.1/410/2009).

Ernanda Kusuma Dewi dan Ayu Lestari. (2017). Peran Pembiayaan Mudharabah Dalam Pengembangan Kinerja Usaha Mikro Pada BMT (Baitul Maal Wat Tamwil), Jurnal Law and Justice, Vol. 2, No. 2.

Fahmi, Irham. (2012). Analisis Kinerja Keuangan. Bandung:Alfabeta, h.68.

Felani, H. Setiawiani, I.G. (2017). Pengaruh Pendapatan Mudharabah, Musyarakah dan Murabahah Terhadap Profitabilitas Bank Umum Syariah Periode 2013-2015. Seminar Nasional dan The $4^{\text {th }}$ Call For Syariah Paper.

Ghufron A.Mas"eadi. (2002). Fiqh Muamalah Kontekstual, Jakarta: PT RajaGrafindo Persada, cet ke-1.

Hamdan. (2013). Pengaruh Pembiayaan Mudharabah dan Musyarakah terhadap NPF pada Bank Umum syariah. Artikel Ilmiah. Surabaya.

Hery. (2015) Analisis Kinerja Manajemen: The Best Financial Analisis Menilai Kinerja Manajemen Berdasarkan Rasio Keuangan. Jakarta: Raja Grafindo Persada. 
Ipat Latipah. (2015) Laba Bank Umum Syariah Ditinjau Dari Pembiayaan Musyarakah, Mudharabah Dan Murabahah. ProdiManajemen Universita Djuanda. Bogor Jawa Barat.

Ismail. (2016). Perbankan Syariah. Jakarta: Kencana.

Kasmir. (2015) Analisis Laporan Keuangan. Jakarta: PT. Grafindo Raja Persada.

Laila R, Euis Komariah. (2017) Pembiayaan Mudharabah dan Musyarakah terhadap Profitabilitas pada Bank Umum Syariah di Indonesia. Jurnal Ilmia MBiA 16 (1).

Mardani, (2014) Hukum Bisnis Syariah, (Jakarta: Prenadamedia Group, cet ke-1.

Medina A., Rina M. (2017). Analisis Pengaruh Pembiayaan Musyarakah terhadap Profitabilitas Bank Syariah di Indonesia. Jurnal Akuntansi $12(2)$.

Muhammad, (2005). Manajemen Pembiayaan Bank Syariah. Yogyakarta: UUP AMP YKPN.

Muhammad. (2017). Manajemen Dana Bank Syariah. Jakarta: Raja Grafindo Persada.

Naf'an. (2014). Pembiayaan Musyarakah dan Mudharabah. Yogyakarta: Graha Ilmu, cet ke-1, 96

Osmad Muthaher. (2012). Akuntansi Perbankan Syariah, (Yogyakarta: Graha Ilmu, 2012).

Sudana. (2015). Manajemen Keuangan Perusahaan. Jakarta: Erlangga.

Sugiono. (2015). Metode Penelitian Pendidikan. Bandung: Alfabeta.

Undang-undang Republik Indonesia Nomor 10 tahun 1998 tentang Pembiayaan

Usanti, Trisadini P. dan Abd. Somad. (2013). Transaksi Bank Syariah. Jakarta: Bumi Aksara.

Wiroso. (2014). Akuntansi Perbankan Syariah dalam PRaktek Di Indonesia. Risalah Perbankan Syariah. Jagakarsa. 
$340\}\{$ Analisis Pembiayaan Musyarakah Terhadap Profitabilitas

..::: Malia: Jurnal Ekonomi Islam, Volume 11 Nomor 2 Juni 2020 :::.. 